\title{
BENEFITS OF AEROBIC EXERCISE TRAINING WITH RECOMMENDATIONS FOR HEALTHY AGING
}

\author{
Enrico REJC ${ }^{1,2}$, Alessio DEL TORTO ${ }^{1,3}$, Stefano LAZZER ${ }^{1,3}$ \\ ${ }^{1}$ Department of Medicine, University of Udine, Italy. \\ ${ }^{2}$ University of Louisville, Department of Neurological Surgery, Louisville, USA. \\ ${ }^{3}$ School of Sport Sciences, University of Udine, Italy. \\ Corresponding author: \\ Prof. Stefano LAZZER \\ University of Udine \\ Department of Medicine \\ P.le Kolbe 4 \\ 33100 Udine, Italy. \\ Phone: +390432494333 - Fax: +390432494301 \\ e-mail: stefano.lazzer@uniud.it
}

\section{ABSTRACT}

The purpose of this articlet is to provide an overview of the importance of aerobic exercise and its characteristics for healthy aging. The first section briefly reviews the effects of aging on maximal aerobic power; Section 2 considers the effects of aerobic exercise training, and Section 3 summarizes the recommendations and some limitations of the current guidelines for aerobic exercise training. Physical activity cannot stop the biological processes; however, there is evidence that regular aerobic exercise can minimize the physiological effects of an otherwise sedentary lifestyle and increase active life expectancy by limiting the development and progression of chronic disease and disability conditions. The use of moderately standardized guidelines for exercise prescription resulted in safe and effective impact on health-related outcomes.

Keywords: aerobic exercise; physical activity; training. 
Enrico REJC, Alessio DEL TORTO, Stefano LAZZER: BENEFITS OF AEROBIC EXERCISE TRAINING WITH RECOMMENDATIONS ..., 111-124

\section{POZITIVNI UČINKI AEROBNE VADBE S PRIPOROČILI ZA ZDRAVO STARANJE}

\section{IZVLE $\check{C} E K$}

Namen tega članka je podati pregled razpoložljivih informacij o pomenu aerobne vadbe in njenih lastnosti za zdravo staranje. V prvem delu so na kratko predstavljeni učinki staranja na maksimalno aerobno moč. Drugi del obravnava učinke aerobne vadbe, medtem ko so v tretjem delu povzeta priporočila ter nekatere omejitve trenutno veljavnih smernic za aerobno vadbo. Telesna aktivnost ne more ustaviti bioloških procesov. Kljub temu pa je na voljo precej dokazov, da redna aerobna vadba zmanjšuje fiziološke učinke sicer sedentarnega življenjskega sloga ter obenem podaljšuje pričakovano življenjsko dobo s tem, ko omejuje nastanek in razvoj kroničnih bolezni ter pogojev invalidnosti. Uporaba zmernih standardiziranih smernic pri predpisovanju telesne vadbe, se odraža neposredno $v$ varnih in učinkovitih vplivih na zdravje in z zdravjem povezana pričakovanja.

Ključne besede: aerobna vadba, telesna aktivnost, vadba.

\section{INTRODUCTION}

The most widely used terms of maximal aerobic functional power are peak and maximum oxygen uptake ( $\mathrm{V}^{\prime} \mathrm{O}_{2}$ peak and $\mathrm{V}^{\prime} \mathrm{O}_{2} \mathrm{max}$ ). Both terms are often used as though they are synonymous, but there are important distinctions to be made between them (Whipp, Davis, Torres, \& Wasserman, 1981). While the $\mathrm{V}^{\prime} \mathrm{O}_{2}$ peak is easier to define and determine, its relevance to physiological and patho-physiological functioning is less secure. It is, simply, the highest value of $\mathrm{V}^{\prime} \mathrm{O}_{2}$ attained on the particular test, most commonly an incremental or other high-intensity test designed to bring the subject to the limit of tolerance - neglecting considerations of what time, or breath-number, frame of reference is chosen for the determination. Unfortunately, it is the highest value achieved regardless of the subject's effort. And so while it defines the highest $\mathrm{V}^{\prime} \mathrm{O}_{2}$ that was attained during the test it does not necessarily define the highest value attainable by the subject. This value is the $\mathrm{V}^{\prime} \mathrm{O}_{2}$ max: a term introduced by Hill and Lupton in 1923 (Hill \& Lupton, 1923) as "the oxygen intake during an exercise intensity at which actual oxygen intake reaches a maximum beyond which no increase in effort can raise it"; its rigorous determination depends on a particular criterion having been met. Considering this, the demonstration $\mathrm{V}^{\prime} \mathrm{O}_{2}$ does not continue to increase, or only to increase by a trivially-small amount, despite further increases in work rate "involving a large proportion of muscle mass" i.e., a V'O "plateau" shows results when $\mathrm{V}^{\prime} \mathrm{O}_{2}$ is plotted as a function of work rate. 
Enrico REJC, Alessio DEL TORTO, Stefano LAZZER: BENEFITS OF AEROBIC EXERCISE TRAINING WITH RECOMMENDATIONS ..., 111-124

Cross-sectional studies show that $\mathrm{V}^{\prime} \mathrm{O}_{2}$ peak typically declines $6-10 \%$ per age decade in healthy men and women (Talbot, Metter, \& Fleg, 2000; Wilson \& Tanaka, 2000; Aspenes et al., 2011). However, the older individuals included in these studies conceivably presented favourable genetics as well as lifestyle differences, thus limiting the generalization of findings for their age peers. In a longitudinal study, a decline in peak $\mathrm{V}^{\prime} \mathrm{O}_{2}$ of $20-25 \%$ per decade was shown in 70+ healthy elderly subjects (Fig. 1) (Fleg et al., 2005). Hawkins et al. (Hawkins, Marcell, Victoria Jaque, \& Wiswell, 2001) also subdivided the sample of master athletes by age group and found that loss rates in maximal oxygen uptake $\left(\mathrm{V}^{\prime} \mathrm{O}_{2} \mathrm{max}\right)$ increased with age, from rates similar to those reported for sedentary subjects in the younger master athletes to rates four times greater than sedentary subjects in the older master athletes (Figure 1). The declines of $20-30$ $\%$ per decade most likely reflect the periods of rapid decline associated with reductions in physical activity and exercise. These findings suggest that either accelerates the reduction in $\mathrm{V}^{\prime} \mathrm{O}_{2}$ max or increases the difficulty of maintaining training.

Decline in $\mathrm{V}^{\prime} \mathrm{O}_{2}$ max can be attributed to age-related reductions in both maximal cardiac output $\left(\mathrm{Q}_{\max }\right)$ and maximal arteriovenous oxygen $\left(\mathrm{a}-\mathrm{v} \mathrm{O}_{2}\right)$ difference in sedentary subjects, while in older endurance-trained individuals only the reduction of Q'max might explain the age-induced decline in maximal aerobic power (Ogawa et al., 1992). Maximal heart rate decreases about six to ten beats per minute per decade, and is responsible for much of the age-associated decrease in Q'max (Hawkins et al., 2001). However, a reduction in stroke volume during maximal exercise in older adults also contributes to the decline in cardiac output (Hagberg et al., 1985). In addition, left ventricular ejection fraction appears to be reduced in older adults during maximal exercise compared to young adults (Taylor \& Groeller, 2008; Thomas, Paterson, Cunningham, McLellan, \& Kostuk, 1993). Decreases in vascular capacity and local blood flow regulation, along with a decline in muscle oxidative capacity contribute to the overall reduction in maximal a- $\mathrm{v}_{2}$ difference observed with age (Sagiv, Goldhammer, Ben-Sira, \& Amir, 2010; Toda, 2012). Coupled with poor oxygen delivery mechanisms, mitochondrial alterations also lead to a reduction in maximal capacity to utilize oxygen at the level of active skeletal muscle. For a submaximal exercise bout, cardiac output is lower in older adults, while a-v O2 difference may tend to increase as a compensatory response to maintain $\mathrm{V}^{\prime} \mathrm{O}_{2}$. A reduction in stroke volume appears to be the major factor responsible for the lower cardiac output observed during submaximal exercise (Ogawa et al., 1992). Blood pressure is also higher in absolute as well as relative work rates in older adults as compared to younger adults. In addition, total peripheral resistance is generally higher in older adults for a given exercise intensity (Ogawa et al., 1992).

Although reduced physical activity with age contributes to decrease the maximal aerobic power, similar rates of decline are observed with age even among highly active individuals. However, the $\mathrm{V}^{\prime} \mathrm{O}_{2}$ peak of such athletic persons is substantially higher than that of their age peers (Fleg et al., 1994). Moreover, the cardiovascular (CV) system remains fully adaptable to training at any age (Kohrt et al., 1991) with relative increases in $\mathrm{V}^{\prime} \mathrm{O}_{2} \max$ in adults of any age equivalent to those seen in young individuals. Given the effect of cardio vascular exercise training and greater fitness on CV disease 
Enrico REJC, Alessio DEL TORTO, Stefano LAZZER: BENEFITS OF AEROBIC EXERCISE TRAINING WITH RECOMMENDATIONS ..., 111-124

Figure 1: Cross-sectional versus longitudinal comparison of loss rates in maximal oxygen consumption ( $V^{\prime} \mathrm{O} 2 \mathrm{max}$ ) $[\mathrm{mL} / \mathrm{kg} / \mathrm{min}]$ in men and women master athletes (adapted from Hawkins \& Wiswell, 2003).

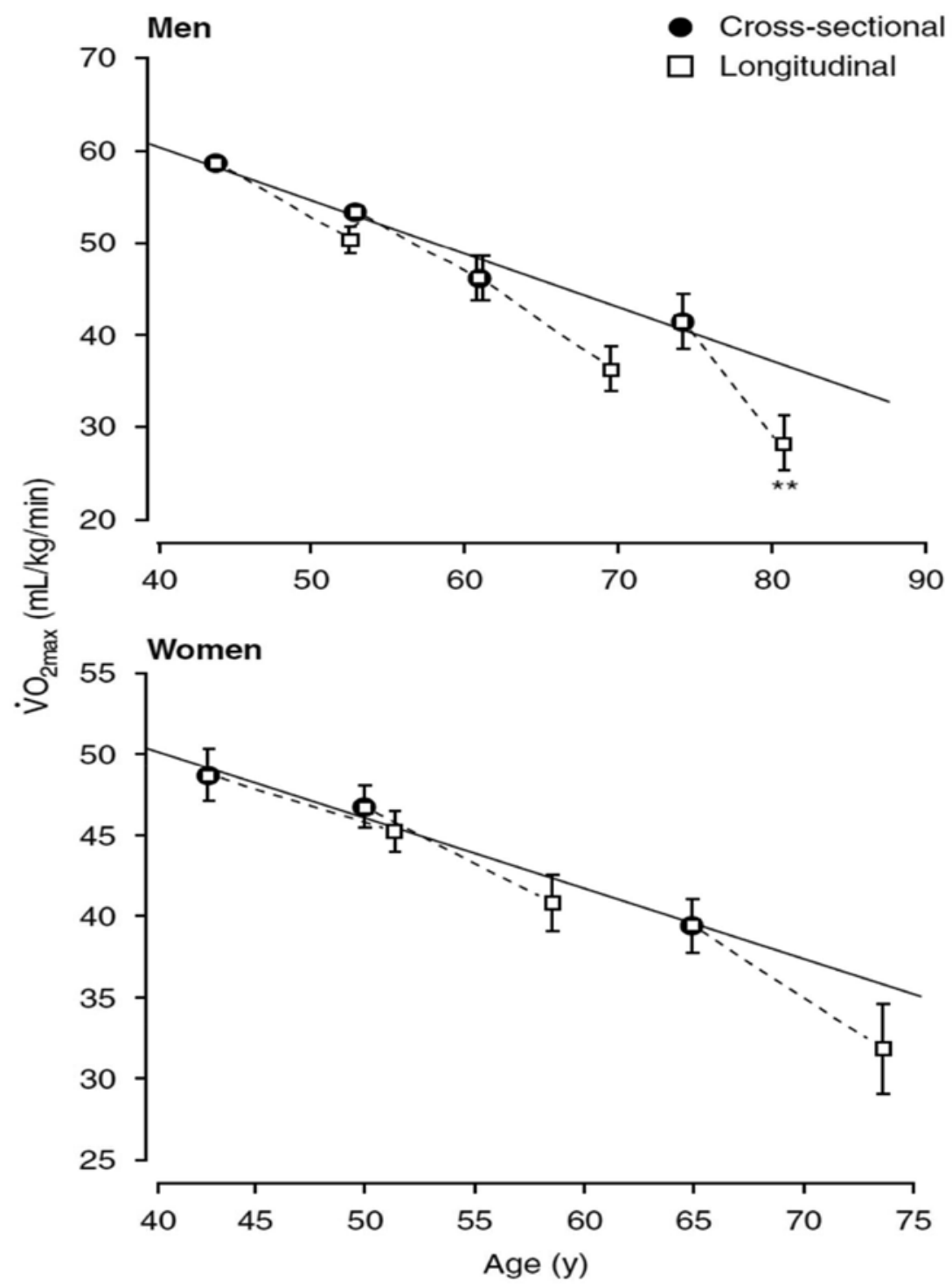

**: Significantly different rate of loss compared with cross-sectional. 
Enrico REJC, Alessio DEL TORTO, Stefano LAZZER: BENEFITS OF AEROBIC EXERCISE TRAINING WITH RECOMMENDATIONS ..., 111-124

risk factors (Kelley \& Sharpe Kelley, 2001), mortality, and all-cause mortality (Myers et al., 2002), recommending aerobic activity to adults of all ages would seem prudent (Balady, 2002).

\section{EFFECTS OF AEROBIC EXERCISE TRAINING}

The ability to maintain high aerobic power is a major determinant of an older adult's functional independence. Several observational studies have demonstrated that endurance athletes, even those in their $60 \mathrm{~s}$ and beyond, maintain a $\mathrm{V}^{\prime} \mathrm{O}_{2}$ peak considerably higher than the one of less active age peers. For example, the $\mathrm{V}^{\prime} \mathrm{O}_{2}$ peak in distance runners aged $60-80$ years was $30-40 \%$ higher than active non-trained age peers in the Baltimore Longitudinal Study of (BLSA). In fact, their aerobic capacity was similar to that of BLSA participants 2 or 3 decades younger (Fleg et al., 1994).

As well, data from the Heritage Family Study suggest that genetics explains $47 \%$ of the $\mathrm{V}^{\prime} \mathrm{O}_{2}$ peak response to 20 weeks of aerobic exercise training after adjustment for age, sex, baseline $\mathrm{V}^{\prime} \mathrm{O}_{2}$ peak, and baseline body mass and composition (Bouchard, 2012). Additionally, multiple studies have documented training-induced increases of $10-25 \%$ in $\mathrm{V}^{\prime} \mathrm{O}_{2}$ peak among adults in their $60 \mathrm{~s}$ to $80 \mathrm{~s}$, and these increases are similar to those in younger adults (Vaitkevicius et al., 2002). A meta-analysis of training studies in persons aged 60 and older found a mean increase in $\mathrm{V}^{\prime} \mathrm{O}_{2}$ peak of $16 \%$ (Huang, Gibson, Tran, \& Osness, 2005). In general, higher intensity training and longer exercise duration elicited greater improvement.

In addition to its beneficial effects on aerobic capacity, exercise training produces multiple benefits that reduce risk factors for $\mathrm{CV}$ disease.

\section{Hypertension}

Hypertension is defined by a systolic blood pressure (BP) $\geq 140 \mathrm{mmHg}$ and / or diastolic $\mathrm{BP} \geq 90 \mathrm{mmHg}$, and it represents the leading risk factor for global burden of disease and mortality (Roger et al., 2012). High blood pressure contributes to $7.0 \%$ of disability-adjusted life-years and 9.4 million deaths. Also, the estimated number of adults with hypertension will be increased to 1.56 billion by 2025 (Hu et al., 2016). The prevalence of hypertension increases with age and it represents a risk factor for the most common causes of morbidity and mortality in older age such as stroke, ischemic heart disease, heart failure and coronary events (Lloyd-Sherlock, Beard, Minicuci, Ebrahim, \& Chatterji, 2014).

In both younger and older persons with hypertension, regular aerobic exercise reduces BP. Important mechanisms contributing to exercise-related BP reduction include a decrease in aortic stiffness and enhanced flow-mediated arterial dilation due to increased nitric oxide release from endothelial cells lining these blood vessels (DeSouza et al., 2000). The reductions in BP from aerobic exercise are often similar to those induced 
Enrico REJC, Alessio DEL TORTO, Stefano LAZZER: BENEFITS OF AEROBIC EXERCISE TRAINING WITH RECOMMENDATIONS ..., 111-124

by a single antihypertensive drug. Mean BP reduction in a large meta-analysis averaged 3.8-2.6 mmHg (Whelton, Chin, Xin, \& He, 2002). It is important to point out that lower intensity exercise equivalent to brisk walking demonstrated BP reductions similar to that of more intensive training in older hypertensive adults (Hagberg, Montain, Martin, \& Ehsani, 1989).

\section{Dyslipidemia}

Abnormal blood lipids are powerful risk factors for CV events in older adults. Aerobic exercise training has beneficial effects on these abnormal lipid levels, irrespective of age. In a meta-analysis of aerobic exercise training trials in older adults, significant increases in high density lipoprotein (HDL) or "good" cholesterol averaged $2.5 \mathrm{mg}$ / $\mathrm{dl}$, and reduced total cholesterol / HDL cholesterol ratio were observed, independent of changes in body composition; improvements in blood lipids correlated with increases in $\mathrm{V}^{\prime} \mathrm{O}_{2}$ peak (Kelley, Kelley, \& Tran, 2005). Weight loss, which is often observed during prolonged training programs, may further improve lipid profile (Katzel et al., 1995).

\section{Glucose Tolerance}

Aging is accompanied by reduced insulin sensitivity, which impairs glucose tolerance. This adaptation often results in type 2 diabetes mellitus, which itself is a potent risk factor for atherosclerotic $\mathrm{CV}$ disease. Both age-associated increase in body fat and reduced physical activity appear to contribute to the impairment of insulin sensitivity and glucose tolerance in older adults. Thus, it is not surprising that both weight reduction and aerobic exercise training ameliorate these impairments. A 9-month aerobic exercise intervention in 71 obese older men $(61 \pm 1$ years, BMI $30.4 \pm 0.4$ [mean \pm SD] ) increased $\mathrm{V}^{\prime} \mathrm{O}_{2}$ peak by a mean of $17 \%(\mathrm{P}<0.001)$ and reduced area (under the glycaemic curve) of an oral glucose tolerance test by an equal amount (Katzel et al., 1995).

\section{Bone Density}

Reduction in bone density associated with aging occurs in both sexes but accelerates in women after menopause, increasing risk for osteoporotic-related fractures, thus, worsening the quality of life. Bonaiuti et al. (2002) reported an increase in bone mineral density of hips and spine by $1.3 \%$ and $0.9 \%$, respectively $(\mathrm{P}=0.055$ and $\mathrm{P}=0.011$, respectively), following walking activity. (Hatori et al., 1993) also showed an increase of bone mineral density of $1.1 \pm 2.9 \%(\mathrm{P}<0.05)$ in postmenopausal healthy women (45 to 67 years) following a 7-month training protocol that consisted of 30 minutes of high-intensity walking performed three times per week. Although estrogen replace- 
Enrico REJC, Alessio DEL TORTO, Stefano LAZZER: BENEFITS OF AEROBIC EXERCISE TRAINING WITH RECOMMENDATIONS ..., 111-124

ment therapy reduces post-menopausal bone loss, the negative cardio vascular effects of estrogen have markedly curtailed its use. It seems worth noting that reduced bone mineral density can represent a potential threat for the health status of an individual. In fact, as mentioned above, reduced bone mineral density can increase the risk of fractures, which affects quality of life and leads to physical inactivity. Fortunately, weight bearing aerobic as well as resistance exercise can increase bone density in older adults by increasing the loading force on bone and stimulating osteoblast activity.

\section{Depression}

In a case-control study, the INERHEART study, it was found that psychological factors (e.g. depression, perceived stress and life events) were strong risk factors for myocardial infarction. Also, depression was officially recognized as a CV risk factor following the 2010 Global Burden of Disease Study and other studies (Yusuf et al., 2004; Elderon \& Whooley, 2013). While it seems important to reiterate that modifiable health behaviour (e.g. physical inactivity, poor diet, smoking, dyslipidemia and medication non-adherence) are conceivably the most critical mediators for $\mathrm{CV}$ disease, the role of depression on CV diseases and physical (in)activity should be considered (Pan, Sun, Okereke, Rexrode, \& Hu, 2011; Hamer, 2012). In fact, some studies reported associations between physical inactivity, depression and CV mortality also in the aged population (Win et al., 2011). In particular, the primary finding of Win and colleagues (2011) was that physical inactivity accounted for approximately $25 \%$ of the increased risk of CV mortality due to depression in community-dwelling aged adults. Furthermore, Whooley et al. (2008) showed that, in a batch of outpatients with stable coronary heart disease, physical inactivity explained almost half of the association between depressive symptoms and CV events. Interestingly, in addition to the beneficial effects of cognitive behavioural therapy and antidepressant medication, regular exercise has been shown to reduce depressive symptoms. For example, Lavie and Milani (1995) have shown lower depression scores, reduced anxiety, and improved total quality of life (QOL) after cardiac rehabilitation (CR) in $85+$ coronary patients. The program lasted 12 weeks in which 36 exercise and educational sessions were performed. Each session included: i) around 10 minutes of warm-up stretching and calisthenics; ii) 30 to 40 minutes of continuous upright aerobic and dynamic exercise (various combinations of walking, bicycling, jogging, rowing, etc.), along with light isometric exercises (e.g. hand weights); iii) around 10-minute cool-down period of stretching. The exercise intensity was prescribed with the aim of making patients attain approximately $75 \%$ to $85 \%$ of their maximal heart rate, or 10 to 15 beats per minute below the level of any exercise induced myocardial ischemia. The exercise prescriptions were periodically adjusted to guarantee a gradual increase in exercise performance. Moreover, all patients were oftentimes supported by physicians, dieticians, nurses, and exercise physiologists to comply with the exercise program (Lavie \& Milani, 1995). 


\section{LONG-TERM BENEFITS OF EXERCISE IN OLDER ADULTS}

Despite the study results on physiological benefits of exercise in older adults reviewed above, elderly people are more concerned about their functional independence and QOL than laboratory measurements. As noted earlier, the ability to perform daily activities generally requires an aerobic power $>20 \mathrm{~mL} / \mathrm{kg} / \mathrm{min}$ (Cress \& Meyer, 2003). Ehsani et al. (2003) reported a V'O $\mathrm{O}_{2}$ peak of $15.6 \pm 2.7 \mathrm{ml} / \mathrm{kg} / \mathrm{min}$ in frail octogenarians women; similarly, (Ades, Ballor, Ashikaga, Utton, \& Nair, 1996) found a peak aerobic power equal to $21.5 \pm 1.1 \mathrm{ml} / \mathrm{kg} / \mathrm{min}$ in old women $(70.4 \pm 4$ years $)$. These findings highlight the fact that older individuals are extremely close to the threshold for loss of independence (Cress \& Meyer, 2003). In this population, regular aerobic training may prevent or significantly delay the crossing of "independence threshold"; furthermore ongoing clinical trials are rigorously examining the effects of regular exercise in preserving independence and reducing morbidity and mortality (Mazzeo \& Tanaka, 2001).

Older adults are conceivably more concerned about their QOL than their longevity per se. Thus, improving and maintaining high QOL assumes great importance in the aged population. Because QOL is adversely impacted by illness and disability, improved physical function might be expected to cause parallel increases in QOL. In HF-ACTION, a trial of supervised aerobic exercise training followed by home exercise in adults with moderate-to-severe CHF, QOL improved significantly with training (Flynn et al., 2009). Similarly Austin, Williams, Ross, Moseley, \& Hutchison (2005) observed improved QOL in 200 patients 60 - 89 years old (mean 72 years) after a 24-week program of aerobic exercise plus low-resistance strength training.

Aging is accompanied by an accelerating reduction of functional capacity, best quantified by $\mathrm{V}^{\prime} \mathrm{O}_{2}$ max and / or $\mathrm{V}^{\prime} \mathrm{O}_{2}$ peak; the degradation of maximal aerobic power is also induced by many comorbidities common to the older individuals (Huggett, Connelly, \& Overend, 2005). However, numerous observational and interventional studies have demonstrated the beneficial effects of exercise training in older adults, both in healthy and diseased individuals (Mazzeo \& Tanaka, 2001). A major challenge confronting the medical community and society is to increase significantly the participation of the aged population in such activities.

\section{RECOMMENDATIONS FOR AEROBIC EXERCISE TRAINING}

Current recommendations for improving $\mathrm{CV}$ fitness and reducing disease risks are certainly effective (Chodzko-Zajko et al., 2009), even though further research is needed to identify the minimum effective dosage for intensity and volume to improve $\mathrm{V}^{\prime} \mathrm{O}_{2 \max }$ and reduce disease and mortality outcomes. These recommendations call for $15-60$ minutes of aerobic activities that include large muscles, rhythmic movement, $3-5$ days per week, at an intensity equivalent to $40-85 \%$ of $\mathrm{V}^{\prime} \mathrm{O}_{2} \max (55-90 \% \mathrm{HRmax})$. This means that practicing exercise at high intensity and volume, just like athletes would, 
Enrico REJC, Alessio DEL TORTO, Stefano LAZZER: BENEFITS OF AEROBIC EXERCISE TRAINING WITH RECOMMENDATIONS ..., 111-124

is not a prerequisite for significant improvements in CV performance and health status in general.

The practice of light- to moderate-intensity physical activity on a more frequent basis, on the other hand, is identified as a requirement to optimize health by the recent guidelines issued by the Centers for Disease Control and Prevention / American College of Sports Medicine (ACSM) (Pate et al., 1995). This should be the main focus of aerobic exercise prescription for adults of all ages (Balady, 2002). Therefore, the ACSM guidelines should provide the basis for exercise prescription for most adults (Chodzko-Zajko et al., 2009). The current consensus recommendations of the ACSM and American Heart Association (AHA) with respect to the frequency, intensity, and duration of exercise and physical activity for older adults are summarized below.

The ACSM / AHA Physical Activity Recommendations are generally consistent with the 2008 Physical Activity Guidelines for Americans by the Department of Health and Human Services (DHHS) (Physical Activities Guidelines Advisory Committee, 2008), which also recommend 150 minutes / week of physical activity for health benefits. However, the DHHS Guidelines note that additional benefits occur as the amount of physical activity increases through higher intensity, greater frequency, and / or longer duration. The DHHS Physical Activity Guidelines point out that if older adults cannot perform 150 min of moderate-intensity aerobic activity per week because of chronic conditions, they should be as physically active as their abilities and conditions allow.

\section{Main recommendations for aerobic exercise training}

Frequency: For moderate-intensity activities, accumulate at least 30 or up to 60 (for greater benefit) minutes / day in bouts of at least 10 min each to total $150-300$ minutes / week, at least $20-30$ minutes / day or more of vigorous-intensity activities to total $75-150$ minutes / week, an equivalent combination of moderate and vigorous activity.

Intensity: On a scale of 0 to 10 for level of physical exertion, 5 to 6 for moderate-intensity and 7 to 8 for vigorous intensity.

Duration: For moderate-intensity activities, accumulate at least 30 minutes / day in bouts of at least 10 min each or at least 20 minutes / day of continuous activity for vigorous-intensity activities.

Type: Any modality that does not impose excessive orthopaedic stress; walking is the most common type of activity. Aquatic exercise and stationary cycle exercise may be advantageous for those with limited tolerance for weight bearing activity.

Despite the extremely favourable health outcomes promoted by the above described physical activity, it may be argued that the proposed exercise guidelines are too generic. The adoption of a common prescription approach may not allow to achieve the full therapeutic potential of physical exercise treatment. In fact, these guidelines do not take into account some crucial aspects of exercise prescription, such as the recovery period among each training session (especially between the ones carried out at high intensity and / or high volume) as well as training periodization and the individualization of 
Enrico REJC, Alessio DEL TORTO, Stefano LAZZER: BENEFITS OF AEROBIC EXERCISE TRAINING WITH RECOMMENDATIONS ..., 111-124

training variables (volume, intensity and frequency) based on the individual needs of the older individuals. In particular, it is known that periodized training promotes better physical improvements compared to non-periodized training programs in the healthy population, and this may conceivably be the case also for non-healthy individuals (Issurin, 2010). Another positive aspect of periodization is the reduced risk of overtraining and its side effects (Fry, Morton, \& Keast, 1992). ACSM guidelines also reported that exercise and physical activity progression for older adults should be individualized, also using exercise tolerance as an additional criteria (Chodzko-Zajko et al., 2009).

\section{CONCLUSIONS}

A body of evidence clearly indicates that involvement in exercise programs induces several benefits for older individuals. These favourable ameliorations involve noteworthy health-related issues including CV disease, metabolic syndrome, diabetes mellitus and osteoporosis. However, not only the cardio-metabolic profile is improved in response to exercise program, indeed, it is reported that physical activity positively affects also more functional benefits that allow for continued independence and the ability to perform daily life activities and reduced cognitive symptoms (e.g. depression and anxiety). As a matter of fact, all these exercise-induced benefits are vanished if the aged population is not involved in a regular physical activity regime. Nowadays, extreme importance is placed on the development of new strategies and educational programs with the aim to inform the older population about the meaningful benefits of regular exercise and increase their involvement, adherence and compliance to such programs.

\section{REFERENCES}

Ades, P. A., Ballor, D. L., Ashikaga, T., Utton, J. L., \& Nair, K. S. (1996). Weight training improves walking endurance in healthy elderly persons. Annals of Internal Medicine, 124(6), 568-572. doi: 10.7326/0003-4819-124-6-199603150-00005 VIEW ITEM

Aspenes, S. T., Nilsen, T. I., Skaug, E. A., Bertheussen, G. F., Ellingsen, O., Vatten, L., \& Wisloff, U. (2011). Peak oxygen uptake and cardiovascular risk factors in 4631 healthy women and men. Medicine \& Science in Sports \& Exercise, 43(8), 1465-1473. doi: 10.1249/MSS.0b013e31820ca81c VIEW ITEM

Austin, J., Williams, R., Ross, L., Moseley, L., \& Hutchison, S. (2005). Randomised controlled trial of cardiac rehabilitation in elderly patients with heart failure. European Journal of Heart Failure, 7(3), 411-417. doi: 10.1016/j.ejheart.2004.10.004 VIEW ITEM

Balady, G. J. (2002). Survival of the fittest--more evidence. New England Journal of Medicine, 346, 852-854. doi: 10.1056/NEJM200203143461111 VIEW ITEM

Bonaiuti, D., Shea, B., Iovine, R., Negrini, S., Robinson, V., Kemper, H. C., ... Cranney, A. (2002). Exercise for preventing and treating osteoporosis in postmenopa- 
Enrico REJC, Alessio DEL TORTO, Stefano LAZZER: BENEFITS OF AEROBIC EXERCISE TRAINING WITH RECOMMENDATIONS ..., 111-124

usal women. Cochrane Database of Systematic Reviews, 2, art. no. CD000333. doi: 10.1002/14651858.CD000333 VIEW ITEM

Bouchard, C. (2012). Genomic predictors of trainability. Experimental Physiology, 97(3), 347-352. doi: 10.1113/expphysiol.2011.058735 VIEW ITEM

Chodzko-Zajko, W. J., Proctor D. N., Fiatarone Singh, M. A., Minson, C. T., Nigg, C. R., Salem, G. J., \& Skinner, J. S., (2009). Exercise and physical activity for older adults. Medicine \& Science in Sports \& Exercise, 41(7), 1510-1530. doi: 10.1249/ MSS.0b013e3181a0c95c VIEW ITEM

Cress, M. E. \& Meyer, M. (2003). Maximal voluntary and functional performance levels needed for independence in adults aged 65 to 97 years. Physical Therapy, 83(1), 37-48. doi: 10.1093/ptj/83.1.37 VIEW ITEM

DeSouza, C. A., Shapiro, L. F., Clevenger, C. M., Dinenno, F. A., Monahan, K. D., Tanaka, H., \& Seals, D. R. (2000). Regular aerobic exercise prevents and restores age-related declines in endothelium-dependent vasodilation in healthy men. Circulation, 102(12), 1351-1357. doi: 10.1161/01.CIR.102.12.1351 VIEW ITEM

Ehsani, A. A., Spina, R. J., Peterson, L. R., Rinder, M. R., Glover, K. L., Villareal, D. T., Binder, E. F. \& Holloszy, J. O. (2003). Attenuation of cardiovascular adaptations to exercise in frail octogenarians. Journal of Applied Physiology, 95(5), 1781-1788. doi: 10.1152/japplphysiol.00194.2003 VIEW ITEM

Elderon, L., \& Whooley, M. A. (2013). Depression and cardiovascular disease. Progress in Cardiovascular Diseases, 55(6), 511-523. doi: 10.1016/j.pcad.2013.03.010 VIEW ITEM

Fleg, J. L., Morrell, C. H., Bos, A. G., Brant, L. J., Talbot, L. A., Wright, J. G., \& Lakatta, E. G. (2005). Accelerated longitudinal decline of aerobic capacity in healthy older adults. Circulation, 112(5), 674-682. doi: 10.1161/CIRCULATIONAHA.105.545459 VIEW ITEM

Fleg, J. L., Schulman, S. P., O'Connor, F. C., Gerstenblith, G., Becker, L. C., Fortney, S., Goldberg, A. P., \& Lakatta, E.G. (1994). Cardiovascular responses to exhaustive upright cycle exercise in highly trained older men. Journal of Applied Physiology, 77(3), 1500-1506. doi: 10.1152/jappl.1994.77.3.1500 VIEW ITEM

Flynn, K. E., Piña, I. L., Whellan, D. J., Lin, L., Blumenthal, J. A., Ellis, S. J., ... Weinfurt, K. P. (2009). Effects of exercise training on health status in patients with chronic heart failure: HF-ACTION randomized controlled trial. JAMA, 301(14), 1451-1459. doi: 10.1001/jama.2009.457 VIEW ITEM

Fry, R. W., Morton, A. R., \& Keast, D. (1992). Periodisation and the prevention of overtraining. Canadian Journal of Sport Sciences, 17(3), 241-248.

Hagberg, J. M., Allen, W. K., Seals, D. R., Hurley, B. F., Ehsani, A. A., \& Holloszy, J. O. (1985). A hemodynamic comparison of young and older endurance athletes during exercise. Journal of Applied Physiology, 58(6), 2041-2046. doi: 10.1152/jappl.1985.58.6.2041 VIEW ITEM

Hagberg, J. M., Montain, S. J., Martin, W. H. 3rd, \& Ehsani, A. A. (1989). Effect of exercise training in 60- to 69-year-old persons with essential hypertension. The American journal of Cardiology, 64(5), 348-353. doi: 10.1016/0002-9149(89)90533-X VIEW ITEM

Hamer, M. (2012). Psychosocial stress and cardiovascular disease risk: the role of physical activity. Psychosomatic Medicine, 74(9), 896-903. doi: 10.1097/PSY.0b013e31827457f4 VIEW ITEM 
Enrico REJC, Alessio DEL TORTO, Stefano LAZZER: BENEFITS OF AEROBIC EXERCISE TRAINING WITH RECOMMENDATIONS ..., 111-124

Hatori, M., Hasegawa, A., Adachi, H., Shinozaki, A., Hayashi, R., Okano, H., ... Murata, K. (1993). The effects of walking at the anaerobic threshold level on vertebral bone loss in postmenopausal women. Calcified Tissue International, 52(6), 411-414. doi: 10.1007/BF00571327 VIEW ITEM

Hawkins, S. A., \& Wiswell, R. A. (2003). Rate and mechanism of maximal oxygen consumption decline with aging: implications for exercise training. Sports Medicine, 33(12), 877-888. doi: 10.2165/00007256-200333120-00002 VIEW ITEM

Hawkins, S. A., Marcell, T. J., Victoria Jaque, S., \& Wiswell, R. A. (2001). A longitudinal assessment of change in VO2max and maximal heart rate in master athletes. Medicine \& Science in Sports \& Exercise, 33(10), 1744-1750. doi: 10.1097/00005768200110000-00020 VIEW ITEM

Hill, A. V., \& Lupton, H. (1923). Muscular exercise, lactic acid, and the supply and utilization of oxygen. Quarterly Journal of Medicine, 16(62), 135-171. doi: 10.1093/qjmed/ os-16.62.135 VIEW ITEM

Hu, Z., Liu, F., Li, M., He, J., Huang, J., Rao, D. C., ... Xueli Yang, X. (2016). Associations of Variants in the CACNA1A and CACNA1C genes with longitudinal blood pressure changes and hypertension incidence: The GenSalt Study, American Journal of Hypertension, 29(11), 1301-1306. doi: 10.1093/ajh/hpw070 VIEW ITEM

Huang, G., Gibson, C. A., Tran, Z. V., \& Osness, W.H. (2005). Controlled endurance exercise training and VO2max changes in older adults: a meta-analysis. Preventive Cardiology, 8(4), 217-225. doi: 10.1111/j.0197-3118.2005.04324.x VIEW ITEM

Huggett, D. L., Connelly, D. M., \& Overend, T. J. (2005). Maximal aerobic capacity testing of older adults: a critical review. The Journals of Gerontology. Series A, Biological Sciences and Medical Sciences, 60(1), 57-66. doi: 10.1093/gerona/60.1.57 VIEW ITEM

Issurin, V. B. (2010). New horizons for the methodology and physiology of training periodization Sports Medicine, 40(3) 189-206. doi: 10.2165/11319770-000000000-00000 VIEW ITEM

Katzel, L. I., Bleecker, E. R., Colman, E. G., Rogus, E. M., Sorkin, J. D., \& Goldberg, A. P. (1995). Effects of weight loss vs aerobic exercise training on risk factors for coronary disease in healthy, obese, middle-aged and older men. A randomized controlled trial. JAMA, 274(24), 1915-1921. doi: 10.1001/jama.1995.03530240025035 VIEW ITEM

Kelley, G. A, Kelley, K. S., \& Tran, Z. V. (2005). Exercise, lipids, and lipoproteins in older adults: a meta-analysis. Preventive Cardiology, 8(4), 206-214. doi: 10.1111/j.0197-3118.2005.03769.x VIEW ITEM

Kelley, G. A., \& Sharpe Kelley, K. (2001). Aerobic exercise and resting blood pressure in older adults: a meta-analytic review of randomized controlled trials. Journals of Gerontology. Series A, Biological Sciences and Medical Sciences, 56(5), M298-303. doi: 10.1093/gerona/56.5.M298 VIEW ITEM

Kohrt, W. M., Malley, M. T., Coggan, A. R., Spina, R. J., Ogawa, T., Ehsani, A. A., ... Holloszy, J. O. (1991). Effects of gender, age, and fitness level on response of VO$2 \mathrm{max}$ to training in 60-71 yr olds. Journal of Applied Physiology, 71(5), 2004-2011. doi: 10.1152/jappl.1991.71.5.2004 VIEW ITEM

Lavie, C. J, \& Milani, R. V. (1995). Effects of cardiac rehabilitation and exercise training on exercise capacity, coronary risk factors, behavioral characteristics, and quality of life in women. The American journal of Cardiology, 75(5), 340-343. doi: 10.1016/S00029149(99)80550-5 VIEW ITEM 
Enrico REJC, Alessio DEL TORTO, Stefano LAZZER: BENEFITS OF AEROBIC EXERCISE TRAINING WITH RECOMMENDATIONS ..., 111-124

Lloyd-Sherlock, P., Beard, J., Minicuci, N., Ebrahim, S., \& Chatterji, S. (2014). Hypertension among older adults in low- and middle-income countries: prevalence, awareness and control. International Journal of Epidemiology, 43(1), 116-128. doi: 10.1093/ije/ dyt215 VIEW ITEM

Mazzeo, R. S., \& Tanaka, H. (2001). Exercise prescription for the elderly: current recommendations. Sports Medicine, 31(11), 809-818. doi: 10.2165/00007256-20013111000003 VIEW ITEM

Myers, J., Prakash, M., Froelicher, V., Do, D., Partington, S., \& Atwood, J. E. (2002). Exercise capacity and mortality among men referred for exercise testing. New England Journal of Medicine, 346, 793-801. doi: 10.1056/NEJMoa011858 VIEW ITEM

Ogawa, T., Spina, R. J., Martin, W. H. 3rd, Kohrt, W. M., Schechtman, K. B., Holloszy, J. O., \& Ehsani, A. A. (1992). Effects of aging, sex, and physical training on cardiovascular responses to exercise. Circulation, 86(2), 494-503. doi: 10.1161/01.CIR.86.2.494 VIEW ITEM

Pan, A., Sun, Q., Okereke, O. I., Rexrode, K. M., \& Hu, F. B. (2011). Depression and risk of stroke morbidity and mortality: a meta-analysis and systematic review. JAMA, 306(11), 1241-1249. doi: 10.1001/jama.2011.1282 VIEW ITEM

Pate, R. R., Pratt, M., Blair, S. N., Haskell, W. L., Macera, C. A., Bouchard, C., ... Wilmore, J. H. (1995). Physical activity and public health. A recommendation from the Centers for Disease Control and Prevention and the American College of Sports Medicine. JAMA, 273(5), 402-407. doi: 10.1001/jama.1995.03520290054029 VIEW ITEM

Physical Activities Guidelines Advisory Committee. (2008). Physical activity guidelines advisory committee report. Washington (DC): US Department of Health and Human Services.

Roger, V. L., Go, A. S., Lloyd-Jones, D. M., Benjamin, E. J., Berry, J. D., Borden, W. B., ... Turner, M. B. (2012). Heart disease and stroke statistics--2012 update: a report from the American Heart Association. Circulation 125(1), e2-e220. doi: 10.1161/ CIR.0b013e31823ac046 VIEW ITEM

Sagiv, M., Goldhammer, E., Ben-Sira, D., \& Amir, R. (2010). Factors defining oxygen uptake at peak exercise in aged people. European Review of Aging and Physical Activity, 7, 1-2. doi: 10.1007/s11556-010-0061-x VIEW ITEM

Talbot, L. A., Metter, E. J., \& Fleg, J. L. (2000). Leisure-time physical activities and their relationship to cardiorespiratory fitness in healthy men and women 18-95 years old. Medicine \& Science in Sports \& Exercise, 32(2), 417-425. doi: 10.1097/00005768200002000-00024 VIEW ITEM

Taylor, N. A. S., \& Groeller, H. (Eds.) (2008). Physiological bases of human performance during work and exercise. Churchill Livingstone: Elsevier.

Thomas, S. G., Paterson, D. H., Cunningham, D. A., McLellan, D. G., \& Kostuk, W. J. (1993). Cardiac output and left ventricular function in response to exercise in older men. Canadian Journal of Physiology and Pharmacology, 71(2), 136-144. doi: 10.1139/ y93-019 VIEW ITEM

Toda, N. (2012). Age-related changes in endothelial function and blood flow regulation. Pharmacology \& Therapeutics, 133(2), 159-176. doi: 10.1016/j.pharmthera.2011.10.004 VIEW ITEM

Vaitkevicius, P. V., Ebersold, C., Shah, M. S., Gill, N. S., Katz, R. L., Narrett, M. J., ... Fleg, J. L. (2002). Effects of aerobic exercise training in community-based subjects 
Enrico REJC, Alessio DEL TORTO, Stefano LAZZER: BENEFITS OF AEROBIC EXERCISE TRAINING WITH RECOMMENDATIONS ..., 111-124

aged 80 and older: a pilot study. Journal of the American Geriatrics Society, 50(12), 2009-2013. doi: 10.1046/j.1532-5415.2002.50613.x VIEW ITEM

Whelton, S. P., Chin, A., Xin, X., \& He, J. (2002). Effect of aerobic exercise on blood pressure: a meta-analysis of randomized, controlled trials. Annals of Internal Medicine, 136(7), 493-503. doi: 10.7326/0003-4819-136-7-200204020-00006 VIEW ITEM

Whipp, B. J., Davis, J. A., Torres, F., \& Wasserman, K. (1981). A test to determine parameters of aerobic function during exercise. Journal of Applied Physiology. Respiratory, environmental and exercise physiology, 50(1), 217-221. doi: 10.1152/jappl.1981.50.1.217 VIEW ITEM

Whooley, M. A., de Jonge, P., Vittinghoff, E., Otte, C., Moos, R., Carney, R. M., ... Browner, W. S. (2008). Depressive symptoms, health behaviors, and risk of cardiovascular events in patients with coronary heart disease. JAMA, 300(20), 2379-2388. doi: 10.1001/jama.2008.711 VIEW ITEM

Wilson, T. M., \& Tanaka, H. (2000). Meta-analysis of the age-associated decline in maximal aerobic capacity in men: relation to training status. American Journal of Physiology. Heart and Circulatory Physiology, 278(3), H829-H834. doi: 10.1152/ ajpheart.2000.278.3.H829 VIEW ITEM

Win, S., Parakh, K., Eze-Nliam, C. M., Gottdiener, J. S., Kop, W. J., \& Ziegelstein, R. C. (2011). Depressive symptoms, physical inactivity and risk of cardiovascular mortality in older adults: the Cardiovascular Health Study. Heart, 97(6), 500-505. doi: 10.1136/ hrt.2010.209767 VIEW ITEM

Yusuf, S., Hawken, S., Ounpuu, S., Dans, T., Avezum, A., Lanas, F., ... Lisheng, L. (2004). Effect of potentially modifiable risk factors associated with myocardial infarction in 52 countries (the INTERHEART study): case-control study. Lancet 364(9438), 937-952. doi: 10.1016/S0140-6736(04)17018-9 VIEW ITEM 